\title{
HEALING POTENTIAL OF A POLYHERBAL OINTMENT ON EXCISION WOUND IN NORMAL AND DIABETES-INDUCED ALBINO RATS
}

\author{
KADHIRAVAN M, KEERTHANA K, SHOBANA G, JOTHI G*, RADHIKA J \\ Department of Biochemistry, Center for Research, SRRCARB, Srimad Andavan Arts and Science College (Autonomous), \\ Tiruchirappalli - 620 005, Tamil Nadu, India. Email: jothi173@yahoo.com
}

Received: 08 March 2016, Revised and Accepted: 12 December 2016

\section{ABSTRACT}

Objective: Wound healing potential of a polyherbal ointment (PHO) prepared from Cordia obliqua Willd., Loranthaceae family (L.f) Ettingsh., and Vigna radiata Linn. has been evaluated, preclinical studies were carried out using albino rats as experiment models.

Methods: Animals were divided into six groups, each group comprised of 6 rats. Groups I, II and III were normal excision wounded rats that were categorized as normal untreated, PHO treated and standard ointment treated, respectively. Groups IV, V and VI were induced with diabetes using alloxan monohydrate (150 mg/kg bw.; i.p single dose) and grouped into diabetic untreated, PHO treated and standard ointment treated, respectively. The PHO was prepared using aqueous extracts of plants in equal proportion with simple ointment base (15\% w/w). The physical, biochemical, and enzymatic parameters studied were rate of wound contraction, ascorbic acid, hydroxyproline, hexosamine, superoxide dismutase (SOD), lipid peroxide (LPO), serum protein, granulation tissue protein, serum glucose, DNA, RNA, platelet, and white blood cells.

Results: The excision wounded animals treated with PHO showed a higher rate of contraction and epithelialization during the treatment period. Group II showed 100\% and Group V showed 90\% wound contraction at the end of experimental period. Hydroxyproline, hexosamine, ascorbic acid, tissue protein, DNA, RNA levels and SOD activity were increased significantly ( $<<0.05)$, LPO, platelet and serum protein level were decreased with PHO treated groups compared to control and standard groups.

Conclusion: This study substantiates the traditional claims of plants prepared as PHO possessing significant wound healing promoting activity and provides scientific evidence to the ethnomedicinal property of plants in healing wounds.

Keywords: Wound healing, Polyherbal ointment, Hydroxyproline, Hexosamine, Excision wound, Cordia obliqua Willd., Dentophote falcate (L.f) Ettingsh., Vigna radiata Linn.

(C) 2017 The Authors. Published by Innovare Academic Sciences Pvt Ltd. This is an open access article under the CC BY license (http://creativecommons. org/licenses/by/4. 0/) DOI: http://dx.doi.org/10.22159/ajpcr.2017.v10i4.11589

\section{INTRODUCTION}

Diabetic patients are more susceptible to delayed wound healing. Wound infection rate was found to be $11 \%$ higher in diabetic patients than in general patient's population [1]. Diabetic wounds are chronic wounds or lesions that take long time to heal, fail to heal or recur. All the phases of healing process such as inflammation, proliferation, maturation, and reepithelialization are disrupted in diabetes mellitus [2]. Many drugs used currently are expensive and may also have side effects on prolonged usage. These forced researchers to search drugs, which are inexpensive, safe, biodegradable, have less side effects and which will be able to act for longer periods before resistance sets in. More than $80 \%$ of the world's population still depends on traditional medicines for various skin diseases $[3,4]$. A large number of plants are used by folklore traditions in India for treatment of cuts, wounds, and burns and also ethnic drugs have been the new source of drugs for various other critical ailments. Herbal medicines used to treat wounds provide disinfection, debridement, and a moist environment to encourage the establishment of the suitable environment for natural healing process [5]. Plant-based extracts and ointments used for external application are safe and enhances the regeneration of the tissues. Herbal ointments with a combination of few medicinal plants help to improve skin texture, regenerate death tissue, purities, and healing effects of wounds [6]. This investigation aims in evolving an effective polyherbal ointment (PHO) using Cordia obliqua Willd., Dentophote falcate (L.f) Ettingsh., and Vigna radiata Linn., belonging to the family of Boraginaceae, Loranthaceae, and Fabaceae.

\section{METHODS}

Collection of plant material

Plant materials used for this study were collected from Kondayampatti in Madurai. The materials were identified and authenticated by Taxonomist Rev. Fr. Dr. John Britto, Director, Rapinat Herbarium, St. Joseph's College, Tiruchirappalli, Tamil Nadu, India.

\section{PHO preparation}

The extract ointment was prepared from the $C$. obliqua Willd., D. falcate (L.f) Ettingsh., and $V$. radiata Linn., mixed with the concentration of $15 \%$ of $(\mathrm{w} / \mathrm{w})$ using simple ointment base. The plant materials were shade dried and ground into coarsely powder using electrical blender. It was then passed through a sieve of 80 mesh size. The plants were mixed in the ratio of $6: 6: 3$, respectively.

- Petroleum gel: $-20 \mathrm{~g}$

- White wax: $-5 \mathrm{~g}$

- C. obliqua Willd.: -6 g (bark)

- D. falcate (L.f) Ettingsh.: -6 g (leaf)

- $\quad$ V radiata Linn.: -3 g (seeds)

Boiled the wax removed from heat and added the petroleum gel and plant materials to the mixture. Stirred continuously until ointment consistency was obtained and used for treating wounded animals.

\section{Experimental animal}

Healthy adult Wistar strain of albino rats of either sex, weighing 150$200 \mathrm{~g}$ were used as experimental models. Animals were kept in well- 
ventilated cages and fed with standard rat chow pellet obtained from Sai Durga Food and Feeds, Bangalore, India, and water ad-libitum. All the studies were conducted according to the ethical guidelines of CPCSEA after obtaining necessary clearance from the committee (approval No: 790/03/ac/CPCSEA). The rats were divided into six groups each containing of six animals.

Group I: Excision wounded animals without treatment

Group II: Excision wounded animals treated with PHO $(0.5 \mathrm{~g})$ for 14 days

Group III: Excision wounded animals treated with standard drug (SD) soframycin ointment $(0.5 \mathrm{~g})$ for 14 days

Group IV: Diabetic excision wounded animals without treatment

Group V: Diabetic excision wounded animals treated with PHO (0.5 g) for 14 days

Group VI: Diabetic Excision wounded animals treated with standard drug (SD) bactibade ointment ( $0.5 \mathrm{~g}$ ) for 14 days.

\section{Excision wound}

An excision wound was created on the dorsal side of rats. The dorsal side of rats was shaved with a razor blade. Excision wound of size $2 \mathrm{~cm}$ areas of skin in length, $0.2 \mathrm{~cm}$ in depth were created using surgical scissors [7]. Hemostasis was achieved by blotting the wound with cotton swab soaked in normal saline. After $2 \mathrm{hrs}$, the dead tissue was excised and the treatment was started. All the rats were given regular dressing changes and kept for observation.

\section{Induction of diabetes in rats}

Diabetes mellitus was induced in a batch of normoglycemic albino rats, starved for $16 \mathrm{hrs}, 150 \mathrm{mg} / \mathrm{kg}$ body weight of alloxan monohydrate was dissolved in physiological saline and injected intraperitoneally [8]. This dose of alloxan produced persistent hyperglycemia after 4 days as revealed by determination of urine sugar levels by BQR method. The diabetes-induced rats were chosen and grouped for further studies.

\section{Measurement of wound contraction [9]}

An excision wound was traced by following the progressive changes in wound area planimetrically, excluding the day of wounding. The size of wounds was traced on a transparent paper in every day, throughout the monitoring period. The tracing was then shifted to graph paper, from which the wound surface area was evaluated. The evaluated surface area was then employed to calculate the percentage of wound contraction, taking initial size of wound, $200 \mathrm{~mm}^{2}$, as $100 \%$, using the following formula:

$$
\% \text { wound contraction }=\frac{\begin{array}{l}
\text { Initial wound size }- \text { Specific day } \\
\text { wound size }
\end{array}}{\text { Initial wound size }} \times 100
$$

\section{Determination of wound contraction}

The rate of wound contraction was determined by the reduction in wound size. The wound site was measured regularly by tracing wound site with trace paper and measured graphically. The standard deviations and mean deviations were given in $\mathrm{cm} \mathrm{[10].}$

\section{Biochemical parameters}

For estimations of hydroxyproline and hexosamine, the acid hydrolysate of the dry tissue samples was used [11,12]. Granulation tissues were extracted with 5\% trichloroacetic acid and incubated overnight with $10 \%$ perchloric acid. They were centrifuged after incubated and washed with $5 \%$ perchloric acid. The precipitate was dissolved in warm $10 \%$ perchloric acid and the DNA and RNA contents were measured. Blood glucose content serum and tissue protein were also estimated [13-16].

\section{Antioxidant assay and hematology studies}

The granulation tissue was excised from the animals, rinsed in ice-cold normal saline, they were homogenized, using appropriate buffer. Lipid peroxidation was determined by analyzing the levels of thiobarbituric acid reactive substances, superoxide dismutase (SOD), the activity of ascorbic acid, white blood cell (WBC), and platelet count [17-21] were also assayed.

\section{Statistical analysis}

Experimental data were expressed as mean \pm standard error of mean. Statistical analysis was performed using analysis of variance between PHOs treated with control groups. Data were considered to be significant at $\mathrm{p}<0.05$.

\section{RESULTS AND DISCUSSION}

The results of preliminary phytochemical screening of drug powder and aqueous extract of plants revealed the presence of flavonoid, alkaloid, sugar, coumarin, and quinine in D. falcate (L.f) Ettingsh. Flavonoid, phenolic compound, and coumarin present in C. obliqua Willd. Flavonoid and alkaloid were present in V. radiata Linn. Flavonoids have been documented to possess potent antioxidant and free radical scavenging effect, which is believed to be one of the most important components of wound healing [22]. They are responsible for wound contraction and increased rate of epithelialization [23]. Presence of flavonoids and alkaloids in plants under study attributes to its healing potential.

Table 1 shows the effect of PHO on normal and diabetic excision wounded models. Rate of wound contraction in untreated, PHO and SD treated normal and diabetic rats on $0^{\text {th }}, 7^{\text {th }}$ and $14^{\text {th }}$ day clearly substantiated by Fig. 1. Percentage wound contraction was found to be greater in PHO treated normal excision wounded rats (Group II - 100\%) compared to diabetic excision wounded PHO treated rats (Group V - 90\%). Wound contraction rate was delayed in diabetic rats compared to normal (nondiabetic) rats [24]. Diabetes can produce many molecular and cellular abnormalities such as connective tissue abnormality including loss of tissue integrity, weak tensile strength, and decreased elasticity. In diabetic patient decrease in collagen content of cutaneous layer of skin can generate impaired and nonhealing abnormalities in wound area [25]. However, PHO under study enhanced wound contraction in diabetic wounded rats compared to untreated diabetic rats (Group IV).

Table 2 depicts the levels of hydroxyproline, hexosamine, protein, glucose, DNA and RNA in the granulation tissues of control and treated groups of normal and diabetes-induced experimental models. Increased hydroxyproline content indicated the increased collagen synthesis, regeneration, and repair of wounded tissues. Collagen as a principal extracellular protein is indispensible for the development of granulation tissue and healing process. Collagen plays a vital role in the hemostasis in addition provides integrity and strength to the tissue matrix [26]. Animals applied with PHO showed profound increase in the level of hydroxyproline and hexosamine thereby might have contributed in rapid collagen formation and wound healing.

Hexosamine as matrix molecule; forms ground substrate for the synthesis of new extracellular matrix. It concludes increase in the levels of these components during the early stages of wound healing [27]. Increased hexosamine content reflects the stabilization of collagen molecule by enhancing electrostatic and ionic interaction [28].

Treatment with PHO (Groups II and V) increases the tissue and serum protein level compared with control (I and IV) and reference (III and VI)

Table 1: Rate of wound contraction on post wounding days

\begin{tabular}{lllll}
\hline Groups & $\mathbf{0}^{\text {th }}$ day & $\mathbf{7}^{\text {th }}$ day & $\mathbf{1 4}^{\text {th }}$ Day & $\begin{array}{l}\text { Final day wound } \\
\text { contraction in } \\
\text { percentage }\end{array}$ \\
\hline Group I & $2.0 \pm 0.03$ & $1.4 \pm 0.06$ & $0.8 \pm 0.02$ & 60 \\
Group II & $2.0 \pm 0.03^{*}$ & $1.1 \pm 0.04^{*}$ & $0.0 \pm 0.01^{*}$ & $100^{*}$ \\
Group III & $2.0 \pm 0.04$ & $1.3 \pm 0.03$ & $0.5 \pm 0.02$ & 75 \\
Group IV & $2.0 \pm 0.03$ & $1.6 \pm 0.02$ & $1.0 \pm 0.01$ & 50 \\
Group V & $2.0 \pm 0.03^{*}$ & $1.1 \pm 0.02^{*}$ & $0.2 \pm 0.01^{*}$ & $90^{*}$ \\
Group VI & $2.0 \pm 0.02$ & $1.5 \pm 0.02$ & $0.6 \pm 0.02$ & 30 \\
\hline
\end{tabular}

Values are expressed as mean \pm SEM. $n=6,{ }^{*} \mathrm{p}<0.05$ when compared

PHO treated (Groups II and V) with control groups (Groups I and IV).

PHO: Polyherbal ointment, SEM: Standard error of the mean 


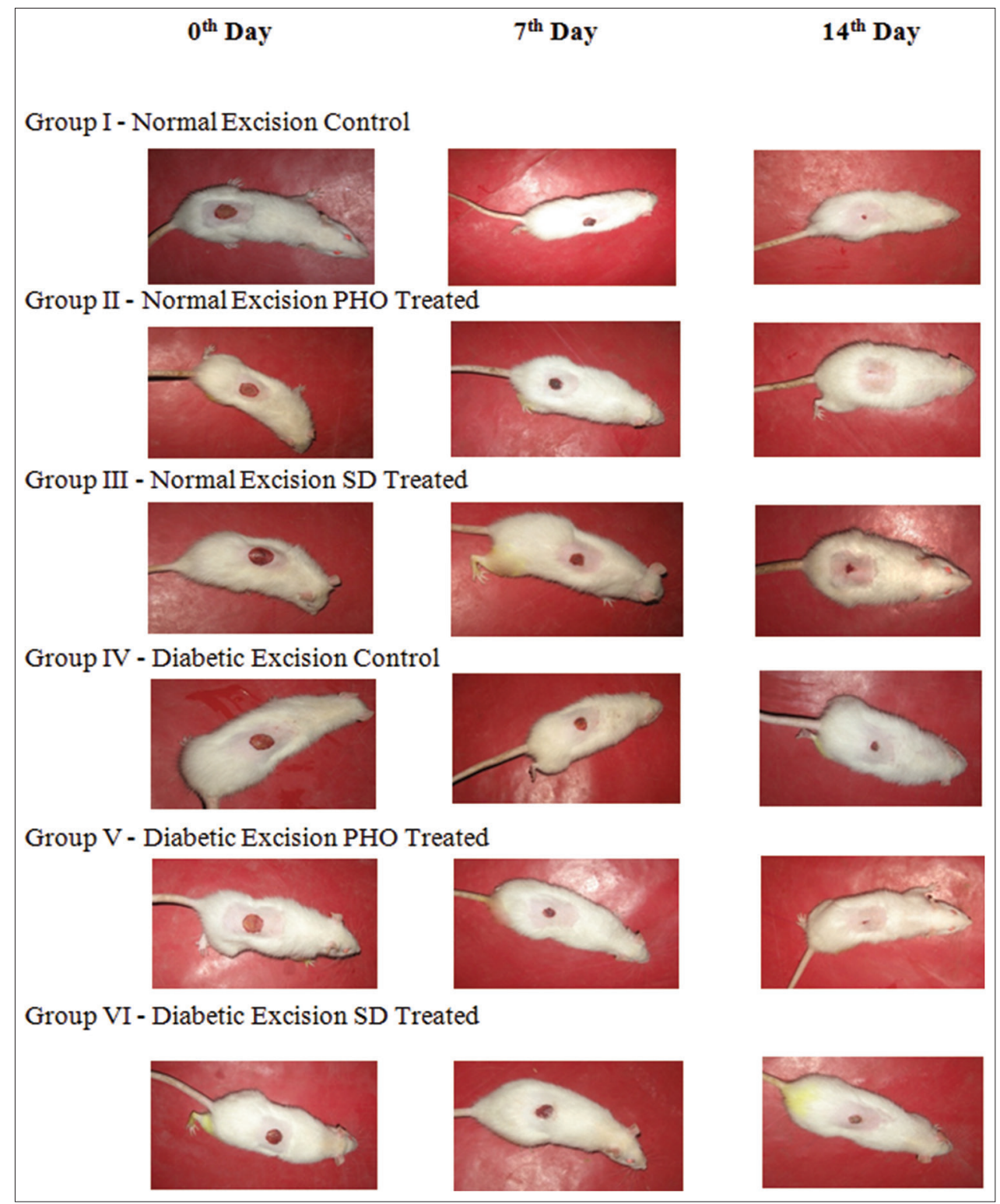

Fig. 1: Wound contraction on post wounding days

Table 2: Effect of polyherbal ointment on biochemical parameters

\begin{tabular}{|c|c|c|c|c|c|c|c|}
\hline Groups & Hydroxyproline (mg/g) & Hexosamine $(\mathrm{mg} / \mathrm{g})$ & $\begin{array}{l}\text { Tissue } \\
\text { protein }(\mathrm{mg} / \mathrm{g})\end{array}$ & $\begin{array}{l}\text { Serum } \\
\text { protein }(\mathrm{mg} / \mathrm{dl})\end{array}$ & $\begin{array}{l}\text { Serum } \\
\text { glucose (mg/dl) }\end{array}$ & DNA (mg/g) & RNA (mg/g) \\
\hline I & $37.46 \pm 6.41$ & $6.8 \pm 0.41$ & $0.6 \pm 0.02$ & $14 \pm 1.02$ & $95 \pm 7.62$ & $2.5 \pm 0.41$ & $1.51 \pm 0.41$ \\
\hline II & $51.29 \pm 4.14^{*}$ & $15.6 \pm 1.04 *$ & $1.2 \pm 0.10^{*}$ & $19 \pm 1.54^{*}$ & $97 \pm 8.41^{*}$ & $5.0 \pm 0.72 *$ & $3.14 \pm 0.32^{*}$ \\
\hline III & $44.14 \pm 4.56$ & $11.6 \pm 0.96$ & $0.8 \pm 0.07$ & $17 \pm 1.28$ & $90 \pm 7.32$ & $3.5 \pm 0.46$ & $2.5 \pm 0.16$ \\
\hline IV & $29.58 \pm 5.11$ & $5.2 \pm 0.51$ & $0.6 \pm 0.02$ & $16 \pm 2.03$ & $182 \pm 10.41$ & $2.5 \pm 0.31$ & $2.1 \pm 0.42$ \\
\hline V & $42.56 \pm 6.21 *$ & $8.8 \pm 0.64 *$ & $1.0 \pm 0.06^{*}$ & $20 \pm 2.51^{*}$ & $189 \pm 12.46^{*}$ & $6.5 \pm 0.32 *$ & $4.01 \pm 0.45^{*}$ \\
\hline VI & $32.07 \pm 5.37$ & $7.1 \pm 0.52$ & $0.8 \pm 0.05$ & $18 \pm 2.01$ & $180 \pm 13.14$ & $5.0 \pm 0.41$ & $3.41 \pm 0.31$ \\
\hline
\end{tabular}

Values are expressed as mean \pm SEM. $n=6,{ }^{*} \mathrm{p}<0.05$ when compared PHO treated (Groups II and V) with control groups (Groups I and IV). PHO: Polyherbal ointment, SEM: Standard error of the mean

wound models. Protein is an indispensible component of the inflammatory process, in the immune response and in the development of granulation tissue $[29,30]$. Concomitant with this there was an increase in the protein content signifying effective synthesis and deposition of matrix proteins in the granulation tissues (Groups II and IV) animals (Table 2).

The level of glucose is maintained normal in Groups I, II and III rats. On induction with alloxan, the blood glucose levels were increased in Groups IV, V and VI rats. Diabetes mellitus produces many molecular and cellular abnormalities such as connective tissue abnormality resulting in loss of tissue integrity, weak tensile strength, and decreased elasticity attributing to poor wound healing. To evaluate the effect of PHO in diabetes-induced wounded rats, the level of glucose was estimated and it was found to be maintained higher throughout the experimental period [25].

PHO treated Groups II and V showed increased level of DNA and RNA content (Table 2) demonstrating the rapid tissue repair and proliferation 
Table 3: Effect of polyherbal ointment on antioxidant assay and hematology studies

\begin{tabular}{llllll}
\hline Groups & SOD (u/mg) & LPO (u/mg) & Ascorbic acid (mg/d) & WBC (thousand cells/cubic mm) & Platelet (lakh cells/cubic mm) \\
\hline I & $6.92 \pm 0.21$ & $5.55 \pm 0.61$ & $0.94 \pm 0.02$ & $9.45 \pm 0.76$ & $2.83 \pm 0.52$ \\
II & $10.15 \pm 0.21^{*}$ & $3.99 \pm 0.42^{*}$ & $2.84 \pm 0.09 *$ & $5.70 \pm 0.82^{*}$ & $1.87 \pm 0.43^{*}$ \\
III & $7.41 \pm 0.34$ & $4.58 \pm 0.61$ & $1.41 \pm 0.07$ & $9.95 \pm 0.42$ & $2.06 \pm 0.35$ \\
IV & $7.14 \pm 0.86$ & $6.55 \pm 0.74$ & $0.72 \pm 0.06$ & $7.55 \pm 0.54$ & $2.69 \pm 0.71$ \\
V & $10.89 \pm 0.76^{*}$ & $4.16 \pm 0.29^{*}$ & $2.14 \pm 0.05^{*}$ & $5.55 \pm 0.62^{*}$ & $0.96 \pm 0.52^{*}$ \\
VI & $8.04 \pm 0.64$ & $5.19 \pm 0.32$ & $1.02 \pm 0.05$ & $6.45 \pm 0.49$ & $1.34 \pm 0.41$ \\
\hline
\end{tabular}

Values are expressed as mean \pm SEM. $n=6,{ }^{*} p<0.05$ when compared PHO treated (Groups II and V) with control groups (Groups I and IV). PHO: Polyherbal ointment, SEM: Standard error of the mean, SOD: Superoxide dismutase, LPO: Lipid peroxide, WBC: White blood cell

compared to reference ointment (III and VI) treated groups. The increased synthesis of DNA, RNA, and protein is responsible for the formation of granulation tissue in response to injury [31]. Significant increase $(\mathrm{p}<0.05)$ in DNA and RNA levels in PHO treated animals (Group II) showed enhanced regeneration of tissue and rapid wound contraction.

Table 3 shows the antioxidant activity of PHO. The levels of lipid peroxide (LPO) were found to be lowered and the activities of SOD were increased in PHO treated animals, WBC and platelet count were also studied. There was a significant $(\mathrm{p}<0.05)$ decrease in the LPO level and marked increase in activity of SOD in the PHO treated groups (II and V) when compared to control (I and IV) and reference ointment (III and VI) groups. This indicates the antioxidant activity of plant in the PHO. The increased activity of SOD content was observed in diabetic excision model compared with normal excision models, which may be due to induction of diabetes.

The ascorbic acid level was increased $(\mathrm{p}<0.05)$ profoundly in the PHO treated groups II and V when compared with control groups I and IV. Ascorbic acid an antioxidant, which can eradicate chained radical reactions by being as a strong electron and proton donor on interactions with free radicals [2]. This was evidenced from profound increase in ascorbic acid level in groups II and V animals.

Tissue injury causes ROS production and lipid peroxidation. Healing process in initiated, LPO level decreases due to increase antioxidant enzyme and repair mechanism. Any drug that increases antioxidant activity contributes significantly in healing process. PHO also enhanced antioxidant status and thereby tissue repair mechanism.

WBC scavenges tissue debris and dead cells from the site of the injury and favors rapid wound healing [32]. Platelets aggregation stimulates fibroblast proliferation and reduces the healing time. Platelet also releases substances that promote tissue repair and influence processes such as angiogenesis, inflammation, and immune response [33].

In this investigation, the total WBC and platelet count on post wounded day $\left(14^{\text {th }}\right)$ showed that there was a decrease in the level in PHO treated groups (II and V) compared to control groups (I and IV) and reference ointment treated Groups III and VI. In PHO treated groups as healing process is completed, the level of WBC resumes to normal but in untreated Groups I and IV as healing process was continuing WBC count was found to be more. Increased level of platelet in untreated groups (I, III, V and VI) showed the clotting of blood and remained in unhealed conditions.

\section{CONCLUSION}

The selected plant source contributed significantly toward the rapid healing process through enhanced wound contraction, rapid rate of collagen synthesis and activated antioxidant system. Thus this study suggests that the C. obliqua Willd., D. falcate (L.f) Ettingsh., and $V$. radiata Linn., extract provides a cumulative effect on the healing of the normal and also diabetic wounds.

\section{REFERENCES}

1. Sharma Y, Jeyabalan G, Singh R, Semwa A. Current aspects of wound healing agents from medicinal plants: A review. J Med Plants Stud 2013;1(3):1-11.
2. Ponrasu T, Subamekala MK, Ganeshkumar M, Suguna L. Role of Annona squamosa on antioxidants during wound healing in streptozotocin - Nicotinamide induced diabetic rats. J Pharmacogn Phytochem 2013;2(4):77-84.

3. Mhatre J, Nagaral S, Kulkarni S. Formulation and evaluation of antibacterial activity of herbal ointment prepared from crude extracts of Aegle marmelos, (Bael). Int J Pharm Pharm Sci 2014;6(2):575-9.

4. Patel NA, Pate M Patel RP. Formulation and evaluation of polyherbal gel for wound healing. Int Res J Pharm 2011;1(1):1-6.

5. Radhika J, Jothi G, Revathy A, Sathya P, Sathya K. Wound healing potentials of Ziziphus mauritiana Lam (bark) in excision wounds in albino rats. Int J Nat Prod Sci 2012;2(1):1-8.

6. Jothi G, Rathika J, Kathija S, Karthikeyan B, Brindha J. Effect of polyherbal ointment on excision and burn wounds in rats. Biomedicine 2010;30(4):465-72.

7. Morton JJ, Malone MH. Evaluation of vulneray activity by an open wound procedure in rats. Arch Int Pharmacodyn Ther 1972;196(1):117-26

8. Szkudelski T. The mechanism of alloxan and streptozotocin action in B cells of the rat pancreas. Physiol Res 2001;50(6):537-46.

9. Sadaf F, Saleem R, Ahmed M, Ahmad SI, Navaid-ul-Zafar. Healing potential of cream containing extract of Sphaeranthus indicus on dermal wounds in Guinea pigs. J Ethnopharmacol 2006;107(2):161-3.

10. Ponnusamy E, Gnanasekaran J, Jeyaraman R. Wound healing efficacy of a polyherbal ointment used to treat incisions, excisions and burn wounds in albino rats. Asian J Tradit Med 2012;7(4):151-8.

11. Woessner JF Jr. Catabolism of collagen and non-collagen protein in the rat uterus during post-partum involution. Biochem J 1962;83:304-14.

12. Wagner WD. A more sensitive assay discriminating galactosamine and glucosamine in mixtures. Anal Biochem 1979;94(2):394-6.

13. Giles KW, Myers A. An improved diphenylamine method for the estimation of deoxyribonucleic acid. Nature 1965;206(4979):93

14. Endo Y. A simultaneous estimation method of DNA and RNA by the orcinol reaction and a study on the reaction mechanism. J Biochem 1970;67(5):629-33.

15. Folin O, Wu H. Determination of glucose. J Biol Chem 1919; XXXViii:81.

16. Lowry $\mathrm{OH}$, Rosebrough NJ, Farr AL, Randall RJ. Protein measurement with the Folin phenol reagent. J Biol Chem 1951;193(1):265-75.

17. Ohkawa H, Ohishi N, Yagi K. Assay for lipid peroxides in animal tissues by thiobarbituric acid reaction. Anal Biochem 1979;95(2):351-8

18. Misra HP, Fridovich I. The role of superoxide anion in the autoxidation of epinephrine and a simple assay for superoxide dismutase. J Biol Chem 1972;247(10):3170-5.

19. Omaye ST, Turnbull JD, Sauberlich HE. Selected methods for the determination of ascorbic acid in animal cells, tissues, and fluids. Methods Enzymol 1979;62:3-11.

20. Armour FE, Blood FR, Belden DA. The Manual for Laboratory Work in Mammalian Phisiology. Vol.3. Illinois: The University of Chicago Press; 1965. p. 4-6.

21. Rusia U, Sood KS. Routine hematological tests in medical laboratory technology - procedure manual for routine diagnostic tests. In: Mukerjee KL, editor. Medical Laboratory Technology. Vol. I. MC Graw Hill Education; 1996. p. 303-7.

22. Shenoy C, Patil MB, Kumar R, Patil S. Preliminary phytochemical investigation and wound healing activity of Allium Cepa Linn (Liliaceae). Int J Pharm Pharm Sci 2009;2(2):167-75.

23. Agarwal PK, Singh A, Gaurav K, Goel S, Khanna HD, Goel RK. Evaluation of wound healing activity of extracts of plantain banana (Musa sapientum var. Paradisiaca) in rats. Indian J Exp Biol 2009;47(1):32-40

24. Mekala S, Kumar MN, Das L, Shetty N, Amuthan A, Vulli V, et al. Evaluation of wound healing activity of ethanolic extract of Lantana 
camara in streptozotocin induced diabetic rats. Int J Pharm Pharm Sci 2014;6(1):631-3

25. Soni R, Mehta NM, Srivastava DN. Healing potential of ethyl acetate soluble fraction of ethanolic extract of Terminalia chebula on experimental cutaneous wounds in streptozotocin induced diabetic rats. Asian J Biomed Pharm Sci 2013;3(25):32-6.

26. Yadav KC, Kumar JR, Basha SI, Deshmukh GR, Gujjula R, Santhamma B. Wound healing activity of topical application of Aloe vera gel in experimental animal models. Int J Pharm Bio Sci 2012;3(2):63-72.

27. Sumitra M, Manikandan P, Suguna L. Efficacy of Butea monosperma on dermal wound healing in rats. Int J Biochem Cell Biol 2004;37(3):566-73.

28. Nayak BS, Raju SS, Ramsubhag A. Investigation of wound healing activity of Lantana camara L. In sprague dawley rats using a burn wound model. Int J Appl Res Nat Prod 2008;1(1):15-9.

29. Perkins L. Nutritional balance in wound healing. Clin Nutr Update 2000;5(1):8-10.

30. MacKay D, Miller AL. Nutritional support for wound healing. Altern Med Rev 2003;8(4):359-77.

31. Holm-Pedersen P, Fenstad AM, Folke LE. DNA, RNA and protein synthesis in healing wounds in young and old mice. Mech Ageing Dev 1974;3(3-4):173-85.

32. Mike C. The meaning of white blood cell counts. Emma Lioyd; 2010. Available from: http://www.brighthub.com/science/medical/ articles/77807.aspx.

33. Nurden AT, Nurden P, Sanchez M, Andia I, Anitua E. Platelets and wound healing. Front Biosci 2008;13:3532-48. 